agriTECH, 40 (3) 2020, 215-222

\title{
Quality of Virgin Coconut Oil with Addition of Peppermint Oil
}

\author{
Clarissa Hanjaya, Franciscus Sinung Pranata, Yuliana Reni Swasti* \\ Faculty of Biotechnology, Universitas Atma Jaya Yogyakarta, Babarsari Street number 44, \\ Yogyakarta 55281, Indonesia \\ ${ }^{*}$ Corresponding author: Yuliana Reni Swasti, Email: yulianareni@gmail.com
}

Submission: February 4, 2019; Received: March 4, 2020

\begin{abstract}
Virgin coconut oil (VCO) is a pure coconut oil made from mature and fresh coconut meat. VCO is consumed for health-related reasons, but the unsaturated fatty acids of VCO are prone to oxidation. Mixing VCO with peppermint oil, which contains antioxidants, inhibits the oxidation of unsaturated fatty acids and thus prevents the rancidity of VCO. This research used the antioxidants from peppermint oil to improve VCO quality. VCO contains antioxidants, such as a-pinene, menthol, 1,8-cineol, camphor, flavonoid, borneol, tocopherol, and carotene. The treatments consisted of three peppermint oil concentrations $(2.5 \%, 5 \%$, and $7.5 \%)$ in VCO. Results showed that the addition of peppermint oil significantly improved VCO quality. The optimal concentration of peppermint oil in VCO was $7.5 \%$ with a water content of $0.05 \%$, a free fatty acid value of $0.13 \%$, a peroxide value of $0.53 \mathrm{mg} \mathrm{eq} / \mathrm{kg}$, an iodine value of $4.42 \mathrm{~g} \mathrm{I}_{2} / 100 \mathrm{~g}$, a total plate count of $0 \mathrm{cfu} / \mathrm{mL}$, and antioxidant activity of $90.28 \%$.
\end{abstract}

Keywords: antioxidant activity; peppermint oil; virgin coconut oil

\section{INTRODUCTION}

Virgin coconut oil (VCO) is edible oil made from mature and fresh coconut meat. VCO is widely used in the food, cosmetics, and pharmaceuticals industries because of its medium chain fatty acids with high antiviral activity and bioavailability (Che Man et al., 1997). Coconut milk (CM) is an oil-in-water emulsion that is stabilized by proteins, such as albumins, phospholipids, and globulins. CM is extracted from coconut meat from mature coconuts (Satheesh and Prasad, 2014)

Unsaturated fatty acids in VCO (10\%) are vulnerable to oxidation (Kamariah et al., 2008). Lipid oxidation is an important factor affecting the shelf life of VCO. Hydroperoxides produced from lipid oxidation decompose into ketones, aldehydes, carboxylic acids, and alcohols. Some of these volatile products affect oil's flavor, even at very low concentrations (Richardsa et al., 2005). Lipid oxidation produces rancid flavor and decreases the nutritional value of VCO through the destruction of essential fatty acids and vitamins (carotene and tocopherol) and the formation of oxidation products, which may cause various diseases (Muik et al., 2005).

The addition of antioxidants can prevent oxidative changes during storage of oil. Antioxidants break the double bonds of oil peroxide compounds, thereby reducing the formation of peroxides that cause rancidity (Wanasundara and Shahidi, 1994). Antioxidants give $\mathrm{H}^{+}$ atoms to free radicals and inhibit oxidation. VCO contains very small amounts of the antioxidant a-tocopherol (Dia et al., 2005).

Synthetic antioxidants, such as Butyl Hydroxy Anisol and Butyl Hydroxy Toluene can be added to a food product to prevent rancidity. However, they may contribute to carcinogenicity and tumorigenicity (Han et al., 2004). Therefore, addition of natural antioxidants is a good solution to overcome the rancidity of VCO. A previous study showed that the natural antioxidant of sesame and clove herbs can reduce the iodine value, PV, and FFA of VCO (Rohaman et al., 1998). Betel oil 5\% contains phenol, kavikol, and eugenol acetyl, which can prevent the rancidity and increase the shelf life of VCO (Utami, 2011). 
Mint leaf (Mentha piperita L.) contains $0.1 \%-1 \%$ peppermint oil (Nurhasanah et al., 2006). Peppermint oil is safe to use in several applications and has high antioxidant and antibacterial activities. The addition of peppermint oil does not change the physical properties of VCO because it is transparent.

In addition, the antioxidant activity of peppermint oil is higher than those of rosemary oil, spearmint oil, and marjoram oil during the chemical composition analysis of essential oil of four lamiaceae herbs (Gharib and da Silva, 2013). Thus, the present study used peppermint oil to improve VCO quality.

This study aimed to determine the effect and the optimal concentration of peppermint oil in VCO. Different concentrations of peppermint oil were added in VCO: $2.5 \%$ for treatment A, $5 \%$ for treatment $B$, and $7.5 \%$ for treatment $\mathrm{C}$. The analysis parameters were iodine value, PV, FFA, water content, antioxidant activity (DPPH test), and TPC value.

\section{MATERIALS AND METHODS}

\section{Materials}

Fresh and mature coconut fruits (Cocos nucifera) (aged from 11-13 months) with medium size were purchased from a local market in Semarang, Indonesia. Clean and fresh mint leaves (Mentha piperita L.) were purchased from a local supermarket in Semarang, Indonesia. The other materials used in this study were ethanol (EtOH), $\mathrm{Na}_{2} \mathrm{~S}_{2} \mathrm{O}_{3}$, anhydrous $\mathrm{Na}_{2} \mathrm{SO}_{4}$, chloroform $\left(\mathrm{CHCl}_{3}\right)$, methanol $(\mathrm{MeOH})$, glacial acetic acid, potassium iodide $(\mathrm{KI})$, iodine solution, bromine, starch, phenolphthalein, $\mathrm{NaOH}$ (Merck, Darmstadt, Germany), 1,1 diphenyl 2 picrylhydrazyl (Sigma-Aldrich, Steinheim, Germany), plate count agar (PCA), and buffered peptone water (BPW) (Oxoid, Basingstoke, United Kingdom).

\section{vCO Production}

Coconut meat from five coconut fruits was grated. The CM from five coconut fruits was extracted with water as much as $2 \mathrm{~L}$. The CM was incubated for $2-2.5$ $\mathrm{h}$ in a closed plastic jar at room temperature, until two layers (skim and cream) were formed (Rahmadi et al., 2013). The cream (supernatant) was separated, stirred, and incubated for $48 \mathrm{~h}$ until three layers (oil, protein, and water) were formed. The oil (the first layer) was separated and filtered with a paper filter.

\section{Peppermint Oil Production by Water and Steam Distillation}

Clean mint leaves were chopped small and placed in a flask with a wire screen barrier. An Erlenmeyer flask was filled with $500 \mathrm{~L}$ of distilled water and placed under a biomass flask. The flask and erlenmeyer were wrapped with aluminum foil and tightly connected to a condenser and chiller, and then the Erlenmeyer flask was heated with a hot plate stirrer. The distillation ended when the droplet mixture stopped. The oil was separated from water and purified with anhydrous $\mathrm{Na}_{2} \mathrm{SO}_{4}$ (Nurhasanah et al., 2006). $\mathrm{Na}_{2} \mathrm{SO}_{4}$ was added to the distillate and mixed it until it produced $\mathrm{Na}_{2} \mathrm{SO}_{4}$ paste in the bottom of the flask.

\section{Application of Peppermint Oil in the VCO}

The peppermint oil was mixed with VCO at $2.5 \%$, $5 \%$, and $7.5 \%$ concentrations in a flask by using a magnetic stirer for $1 \mathrm{~h}$, and the flask was covered with aluminum foil.

\section{Water Content Test}

Water content was analyzed with oven drying. Oil $(5 \mathrm{~g})$ was placed in a weighing bottle with constant weight. The sample was heated $\left(105^{\circ} \mathrm{C}\right)$ for $1 \mathrm{~h}$. The sample was cooled with a desiccator for $10 \mathrm{~min}$. The heating steps were repeated until the constant weight of the sample was obtained. Experiments were carried out in accordance with the methods of AOAC (1995).

\section{Free Fatty Acid (FFA) Test}

FFA was determined by titrimetry. Oil $(30 \mathrm{~g})$ was mixed with $50 \mathrm{~mL}$ of $95 \% \mathrm{EtOH}$. Phenolphthalein was used as an indicator. The mixture was titrated with 0.01 $\mathrm{M} \mathrm{NaOH}$ until a red color formed. Experiments were carried out in accordance with the methods of AOCS (1992).

\section{Iodine Value Test}

The oil $(0.5 \mathrm{~g})$ was mixed with $10 \mathrm{~mL}$ of $\mathrm{CHCl}_{3}$ and $25 \mathrm{~mL}$ of Hanus reagent. The solution was incubated for $30 \mathrm{~min}$ in the dark and then mixed with $10 \mathrm{~mL}$ of $15 \% \mathrm{KI}$ and $100 \mathrm{~mL}$ of distilled water. The mixture was titrated with $0.1 \mathrm{M} \mathrm{Na}_{2} \mathrm{~S}_{2} \mathrm{O}_{3}$ until pale yellow color was formed and the titration continued until the blue color disappears (using starch solution as an indicator). Experiments were carried out in accordance with the methods of AOAC 920.158 (2005).

\section{DPPH Assay}

The sample was mixed with $\mathrm{CHCl}_{3}$ and $\mathrm{MeOH}$ (Kim, 2005) (2:1) solvent with 2:5 ratio. The sample solution $(5 \mathrm{~mL})$ was mixed with $1 \mathrm{~mL}$ of $0.2 \mathrm{mM}$ DPPH solution. The mixture was incubated for $30 \mathrm{~min}$ in the dark. Absorbance of all samples and blank was obtained with a UV-Vis spectrophotometer (Kim, 2005)(517 nm). 
DPPH radical inhibition (\%) was determined by dividing the absorbance difference between the blank and sample by the absorbance of the blank alone and then multiplied by $100 \%$ (Kim, 2005).

\section{Peroxide Value (PV) Test}

Oil $(5 \mathrm{~g})$ was mixed with $30 \mathrm{~mL}$ of $40 \% \mathrm{CHCl}_{3}$ and $60 \%$ acetic acid. The solution was mixed with $1 \mathrm{~g}$ of saturated $\mathrm{KI}$ and incubated in the dark for $30 \mathrm{~min}$. The mixture was mixed with $30 \mathrm{~mL}$ of distilled water and then titrated with $0.1 \mathrm{M} \mathrm{Na}_{2} \mathrm{~S}_{2} \mathrm{O}_{3}$ solution until the yellow color disappears and the titration continued until the blue color disappears (using starch solution as indicator). Experiments were carried out in accordance with the methods of AOAC 965.33 (1969).

\section{Total Plate Count (TPC) Test}

A $1 \mathrm{~mL}$ sample was mixed with $9 \mathrm{~mL}$ of BPW. This mixture $(1 \mathrm{~mL})$ was poured into a sterile Petri dish. PCA was poured into a Petri dish and homogenized. The Petri dish was incubated $\left(37^{\circ} \mathrm{C}\right)$ for $48 \mathrm{~h}$. The TPC test was determined in accordance with the methods of AOAC 966.23 (2000).

\section{RESULTS AND DISCUSSION}

\section{Water Content}

As shown in Table 1, the water content of a VCO sample ranged from $0.05 \%$ to $0.3 \%$. The water content of the VCO control exceeded the standard of VCO (INS 7381-2008), which is not more than $0.2 \%$ (National Standardization Agency, 2008). This result is may be due to the hydrolysis reaction during VCO production after the addition of water during the wet extraction of $\mathrm{CM}$. The stirring of $\mathrm{CM}$ in a short time may also cause incomplete separation of oil from the water. The oil separation $(4 \mathrm{~h})$ in the open space may also cause oil

Table 1. Water content and FFA of VCO with peppermint oil addition

\begin{tabular}{ccc}
\hline $\begin{array}{c}\text { Peppermint oil } \\
\text { concentration } \\
\text { in VCO }\end{array}$ & $\begin{array}{c}\text { Water content } \\
(\%)\end{array}$ & FFA (\%) \\
\hline $0 \%$ & $0.30 \pm 0.18^{\mathrm{a}}$ & $0.25 \pm 0.01^{\mathrm{a}}$ \\
$2.5 \%$ & $0.12 \pm 0.02^{\mathrm{b}}$ & $0.20 \pm 0.01^{\mathrm{b}}$ \\
$5 \%$ & $0.09 \pm 0.01^{\mathrm{b}}$ & $0.18 \pm 0.01^{\mathrm{b}}$ \\
$7.5 \%$ & $0.05 \pm 0.01^{\mathrm{b}}$ & $0.13 \pm 0.03^{\mathrm{c}}$ \\
\hline
\end{tabular}

All values are expressed as means, and those with the same letter within the same column are not significantly different according to DMRT at the $5 \%$ significance level contact with the water phase and water vapor in the air (Anwar \& Salima, 2016).

Hydrolysis reaction can also occur when the sample's bottle cap is opened (allow the oil to contact with water vapor in the air). The high water content initiates the hydrolysis reaction of unsaturated fatty acids. The hydrolysis reaction produces glycerol and FFAs, which may contribute to the rancid flavor of VCO.

Nevertheless, the addition of peppermint oil treatments in VCO exerted a positive effect because their water content was below $0.2 \%$. The high addition of peppermint oil significantly influenced the water content of VCO. The higher the concentration of peppermint oil in VCO, the lower the water content of VCO. This phenomenon may be attributed to the fact that the hydroxyl groups in menthol, as the main component in peppermint oil, may replace the hydrogen bond between water and triglycerides. Thus, the water that attached to the triglycerides evaporated, and the water content of the sample decreased.

\section{Free Fatty Acids}

FFAs that degrade and evaporate produce undesirable flavor in oils (Rohman et al., 2011). The FFAs of a VCO sample ranged from $0.13 \%$ to $0.25 \%$, as shown in Table 1 . The VCO control had a poor quality because it exceeded the standard of VCO (INS $7381-2008$ ) that is not more than $0.2 \%$ (National Standardization Agency, 2008). VCO with the addition of peppermint oil had a good quality because their FFAs were below $0.2 \%$.

The high level of FFAs in the VCO control may be caused by its high water content. The water content may be caused by hydrolysis reaction. The fatty acid composition of VCO showed that VCO had a high saturated fatty acid content of $50.01 \% \pm 1.147 \%$ lauric acid (Onyeike and Acheru, 2002). Hydrolysis reaction converts triglycerides (saturated) into FFAs and glycerol. The high level of FFA is affected by the high water content because water initiates the hydrolysis reaction (Rohman et al., 2011).

The addition of peppermint oil in VCO significantly influenced FFA content. The greater the concentration of peppermint oil in the VCO, the lower the FFA content. This result may be attributed to the low water content when the concentration of peppermint oil was increased. Therefore, the possibility of FFA formation in hydrolysis reaction was also reduced.

\section{Iodine Value}

The iodine value is expressed as the number of grams of iodine per $100 \mathrm{~g}$ of fat or oil. The iodine value gives an estimation of the amount of unsaturated fatty 
Table 2. Iodine value of Virgin Coconut Oil with peppermint oil addition

\begin{tabular}{cc}
\hline $\begin{array}{c}\text { Peppermint oil } \\
\text { concentration in VCO }\end{array}$ & $\begin{array}{c}\text { Iodine value (g iodine } / 100 \\
\mathrm{~g})\end{array}$ \\
\hline $0 \%$ & $10.41 \pm 0.74^{\mathrm{a}}$ \\
$2.5 \%$ & $7.14 \pm 0.41^{\mathrm{b}}$ \\
$5 \%$ & $7.07 \pm 0.63^{\mathrm{b}}$ \\
$7.5 \%$ & $4.42 \pm 0.97^{\mathrm{c}}$ \\
\hline
\end{tabular}

All values are expressed as means, and those with the same letter within the same column are not significantly different according to DMRT at the $5 \%$ significance level

acids in oil (Alam and Uddin, 2017). The high number of unsaturated fatty acids oxidizes VCO easily. The double bond of fatty acid binds $\mathrm{O}_{2}$ to form peroxides that cause rancidity (Tomagolaet al., 2016). The iodine value of VCO was $4.42-10.41 \mathrm{~g}$ iod/100 g, as shown in Table 2. All treatments had a good quality because their iodine values were in the range of VCO standard (INS 7381:2008), which is 4.1-11 g iod/100 g (National Standardization Agency, 2008). The iodine value expresses unsaturated fatty acid constituents of oil. VCO contains high saturated fatty acids (90\%) and only a few unsaturated fatty acids (10\%) (Kamariah et al., 2008). Therefore, the iodine value of VCO is relatively low.

The addition of peppermint oil in VCO significantly influenced the iodine value of VCO. The greater the concentration of peppermint oil, the lower the iodine value. The main fatty acid of peppermint oil was palmitic acid (saturated fatty acid) (McKay and Blumberg, 2006). As a result, the ratio of saturated fatty acid in the VCO with peppermint oil treatment was higher than that in the VCO control. The iodine value indicates the unsaturation of fatty acids of VCO. Thus, the addition of peppermint oil does not increase the iodine value of VCO.

\section{DPPH Assay}

In this study, the DPPH method was performed in the antioxidant activity test. The antioxidant activity was expressed as percent of DPPH radical inhibition. The reaction of DPPH and antioxidant forms 1,1-diphenyl2-picrilhidrazine (Molyneux, 2004). As shown in Table 3 , the antioxidant activiy of VCO ranged from $27.60 \%$ to $90.28 \%$.

The higher the concentration of peppermint oil, the higher antioxidant activity. This result may due to the reaction between the DPPH radical and antioxidant. The reaction decreases the intensity of purple color and turns to yellow when the full amount of the free radical
Table 3. Antioxidant activity of VCO with peppermint oil addition

\begin{tabular}{ccc}
\hline $\begin{array}{c}\text { Peppermint oil } \\
\text { concentration in } \\
\text { VCO }\end{array}$ & $\begin{array}{c}\text { Radical DPPH } \\
\text { inhibition (\%) }\end{array}$ & Color \\
\hline $0 \%$ & $27.60 \pm 2.08^{\text {a }}$ & $\begin{array}{c}\text { Purple slightly } \\
\text { yellow }\end{array}$ \\
$2.5 \%$ & $78.65 \pm 1.04^{\mathrm{b}}$ & Yellow \\
$5 \%$ & $85.94 \pm 1.56^{\mathrm{c}}$ & Yellow \\
$7.5 \%$ & $90.28 \pm 1.97^{\mathrm{d}}$ & Yellow \\
\hline
\end{tabular}

All values are expressed as means, and those with the same letter within the same column are not significantly different according to DMRT at the $5 \%$ significance level

is blocked by the antioxidants (Preedy and Watson, 2010).

The VCO control had a low antioxidant activity of $27.6 \%$. The antioxidant activity of the VCO control was conferred by $0.003 \%$ a-tocopherol in VCO. The a-tocopherol was found in the coconut testa that was removed in VCO production. Therefore, VCO samples only contain a small amount of a-tocopherol (Dia et al., 2005).

The optimal concentration of peppermint oil in VCO was $7.5 \%$. The higher the peppermint oil concentration, the higher the antioxidant activity, which is expressed with low absorbance value in the spectrophometer (Talapessy et al., 2013). Absorbance value decreases because the antioxidant donates $\mathrm{H}^{+}$ion to react with the DPPH radical (Zuhra et al., 2008).

The addition of peppermint oil significantly influenced the antioxidant activity of VCO. Peppermint oil contains antioxidants, such as menthol, camphor, flavonoid, borneol, tocopherol, and carotene (Gharib and da Silva, 2013); tannins (Singh et al., 2015); and 1,8-cineol and a-pinene (Gupta and Saxena, 2010). The main antioxidants from peppermint oil is menthol as terpene, which is nonpolar (Friedrich, 1988).

Terpene has in vitro and in vivo antioxidant activity through a DPPH test (Awouafack et al., 2012). Terpene is a primary antioxidant that donates $\mathrm{H}^{+}$ions or electrons to stabilize free radicals. The double bond in monoterpene is responsible for the neutralization of DPPH radicals (Behrendorff et al., 2013).

The mechanism of terpene's antioxidant activity is by the reaction of antioxidant with peroxyradical and fatty acid radicals by donating $\mathrm{H}^{+}$ion and forms antioxidant radicals $(\mathrm{AH}+\mathrm{R} \rightarrow \mathrm{RH}+\mathrm{A}$ and $\mathrm{AH}+\mathrm{ROO} \rightarrow$ $\mathrm{ROOH}+\mathrm{A})$. Free radicals become inactive, and their formation is terminate. The antioxidant radicals are 
unable to continue the oxidation chain because of the lack of energy to react with other lipid molecules (Pokorny, 1971).

\section{Peroxide Value}

As shown in Table 4, The PV of a VCO sample was $0.53-2.3 \mathrm{mg} \mathrm{eq} / \mathrm{kg}$. The VCO control had poor quality because it exceeded the standard of VCO (INS 7381: 2008) that is not more than $2 \mathrm{mg} \mathrm{eq} / \mathrm{kg}$ (National Standardization Agency, 2008). Peroxides also formed when the $\mathrm{CM}$ was incubated for $2-2.5 \mathrm{~h}$ and when the coconut cream was incubated for $48 \mathrm{~h}$. Incubation in an open state may cause $\mathrm{O}_{2}$ in the air to oxidize the unsaturated fatty acids in VCO and light, which can promote oxidation.

Peroxy radicals are formed when the triglyceride free radical reacts with $\mathrm{O}_{2}$. The peroxy radical reacts with another triglyceride, forming a hydroperoxide and regenerating a new free radical that reacts with another $\mathrm{O}_{2}$, causing an accelerated chain reaction to occur. The unstable hydroperoxides break down to secondary products, which contribute to unpleasant flavors and rancidity (Hamilton and Allen, 1994). The oxidation of unsaturated fatty acids of VCO may occur during the storage (initiation and propagation of lipid oxidation) and form peroxides. Peroxides cause the oxidation reaction and increase the PV until the maximum value. Then, the PV decreases as the peroxides degrade into nonvolatile and volatile components, such as oxidiene, epoxyhydroxy compound, malondialdehyde, aldehydes (hexanal, propanal), ketones, and FFAs (Pignitter and Somoza, 2012).

The addition of peppermint oil significantly influenced the PV of VCO. The VCO with the addition of peppermint oil showed a good quality on the basis of the standard (INS 7381: 2008). The greater the concentration of peppermint oil, the lower the PV. The optimal concentration of peppermint oil in VCO was $7.5 \%$.

Table 4. Peroxide value (PV) of VCO with peppermint oil addition

\begin{tabular}{cc}
\hline $\begin{array}{c}\text { Peppermint oil concentration in } \\
\text { VCO }\end{array}$ & PV (mg eq $/ \mathrm{kg})$ \\
\hline $0 \%$ & $2.30 \pm 0.40^{\mathrm{a}}$ \\
$2.5 \%$ & $1.77 \pm 0.20^{\mathrm{b}}$ \\
$5 \%$ & $1.39 \pm 0.20^{\mathrm{b}}$ \\
$7.5 \%$ & $0.53 \pm 0.23^{\mathrm{c}}$ \\
\hline
\end{tabular}

All values are expressed as means, and those with the same letter within the same column are not significantly different according to DMRT at the $5 \%$ significance level.
This result may be ascribed to the fact that the antioxidants in peppermint can prevent the oxidation reaction. Antioxidants break the double bond of the peroxide compound and decrease the chances of peroxide formation, thereby preventing rancidity (Tomagola et al., 2016). The double bonds react with the active peroxides in the absence of antioxidants. This mechanism prevents peroxide radicals binding $\mathrm{H}^{+}$from fatty acids to form hydroperoxides and new fatty acid radicals (Pokorny, 1971).

\section{Total Plate Count}

As shown in Table 5, the TPC value of VCO was 0-11.67 cfu/mL. On the basis of the TPC value, the VCO control had a poor quality because it exceeded the standard of VCO (INS 7381-2008) that is not more than $10 \mathrm{cfu} / \mathrm{mL}$ (National Standardization Agency, 2008). This phenomenon may be ascribed to contaminations from the coconut meat, the coconut shredding tool, and dirty hands during $\mathrm{CM}$ wet extraction.

The antibacterial activities of VCO against Salmonella thypi and Escherichia coli are relatively low (Loung et al., 2014). The main fatty acid in VCO, lauric acid, also lacks antibacterial activity against Staphylococcus epidermidis, Pseudomonas aeruginosa, Staphylococcus aureus, and Propionibacterium acnes (Silalahi et al., 2014). These bacteria may increase the TPC values of the VCO control.

VCO without peppermint oil treatment is suitable to be sold and consumed. VCO contains antimicrobials from $0.5 \%$ caproate acid and lauric acid. Caproate acid and lauric acid are transformed into monoglycerides (monocaprin and monolaurin) after being consumed (Widiyanti, 2015).

The addition of peppermint oil significantly influenced the TPC value of VCO. The peppermint oil treatments had a good quality because the TPC value was consistent with the standard (INS 7381-

Table 5. Total plate count (TPC) of VCO with peppermint oil addition

\begin{tabular}{cc}
\hline $\begin{array}{c}\text { Concentration of peppermint } \\
\text { oil in VCO }\end{array}$ & TPC value (cfu/mL) \\
\hline $0 \%$ & $11.67 \pm 5.77^{\mathrm{a}}$ \\
$2.5 \%$ & $3.33 \pm 5.77^{\mathrm{b}}$ \\
$5 \%$ & $1.67 \pm 2.89^{\mathrm{b}}$ \\
$7.5 \%$ & $0.00 \pm 0.00^{\mathrm{b}}$ \\
\hline
\end{tabular}

All values are expressed as means, and those with the same letter within the same column are not significantly different according to DMRT at the $5 \%$ significance level 
2008). The higher the peppermint oil concentration in VCO, the lower the TPC value. Thus, the lower of the contamination, and the better the quality.

The addition of peppermint oil treatments in VCO had a good quality in accordance with INS 7381-2008 because peppermint oil has antibacterial activity from menthol against Gram-negative and Gram-positive microbes (Diaz et al., 1988), as well as antiviral and antifungal activities (Chaumont and Packer, 1978). The antibacterial activity of peppermint oil can also inhibit E. coli, S. aureus, P. aeruginosa, Streptococcus faecalis, and Klebsiella pneumoniae (Singh et al., 2015).

Menthol remove resistant plasmids from bacteria (Shrivastava, 2009). It disrupts the structure of bacterial cell membranes and mitochondria. This phenomenon causes the loss of components in bacterial cells (ions and many important molecules) and lead to the death of bacteria through cell lysis (Burt, 2004).

The colorless samples were consistent with the theory that VCO is colorless in a liquid state (Agarwal, 2017). Clear appearance can be obtained because the VCO is filtered by filter paper during oil separation. VCO with peppermint oil addition yielded the same color because peppermint oil is colorless or yellowish or greenish yellow (Shrivastava, 2009). It is affected by the main content inside peppermint oil (monoterpen), and monoterpenes are colorless (Robinson, 1991).

\section{CONCLUSION}

The addition of peppermint oil in VCO reduced the FFA content, water content, PV, TPC value, and iodine value but increased the antioxidant activity of VCO. The optimal concentration of peppermint oil to improve the quality of VCO was $7.5 \%$. The peppermint oil treatment in VCO caused flavor changes, but the amount of peppermint oil was still lower than that of VCO. Thus, the end product is still considered VCO. Nowadays, VCO products with different flavors are being explored in the market.

\section{ACKNOWLEDGMENT}

We thank our colleagues from the Department of Biotechnology Universitas Atma Jaya Yogyakarta Indonesia who provided feedback and insights that greatly improved this manuscript.

\section{CONFLICT OF INTEREST} interest.

\section{REFERENCES}

Agarwal, R. K. (2017). Extraction Processes of Virgin Coconut Oil. MOJ Food Processing \& Technology, 4(2), 2-4. https://doi.org/10.15406/mojfpt.2017.04.00087

Alam, M. K., \& Uddin, M. S. (2017). Characterization of oil and lecithin from pioly (Aspidoparia morar) fish. Journal of Innovations in Pharmaceutical and Biological Sciences (JIPBS), 4(1), 44-48.

Anwar, C., \& Salima, R. (2016). Perubahan rendemen dan mutu virgin coconut oil pada berbagai kecepatan putar dan lama waktu sentrifugasi. Teknotan, 10(2), 51-60.

AOAC. (1969). Official Method 965.33 Peroxide Value of Oils and Fats Titration Method. Association of Official Analytical Chemists.

AOAC. (1995). Official Method of Analysis. Association of Official Analytical Chemists.

AOAC. (2000). Official method Microbiological Method 17 th Edition. Association of Official Analytical Chemists.

AOAC. (2005). Official Methods of Analysis. Association of Official Analytical Chemists.

AOCS. (1992). Official Methods and Recommended Practices of the American Oil Chemists Society (4th ed.). American Oil Chemists Society.

Awouafack, M. D., Pierre, T., \& Jacobus, E. N. (2012). Two new antioxidant flavones from the twigs of Eriosema robustum (Fabaceae). Journal of Phytochemical Society of Europe, 6(1), 62-66.

Behrendorff, B. Y., Vickers, P., Chrysanthopoulos, \& Neilsen, L. K. (2013). 2,2-Diphenyl-1picrylhydrazil as a screening tool for recombinant monoterpene biosynthesis. Microbial Cell Factories, 12(76), 1-11.

Burt, S. (2004). Essential oils : their antibacterial properties and potential applications in foof. Journal of Food Microbiology, 94(3), 223-253.

Chaumont, E., \& Packer, L. (1978). Antagonistic properties of higher plants against fungal parasites of man from food contaminants screening of 200 fungi. Plant Med. Phytother., 12, 186-196.

Che Man, Y. B., Karim, A. M. I. B., \& Teng, C. T. (1997). Extraction of coconut oil with Lactobacillus plantarum 1041 IAM. Journal of the American Oil Chemists' Society, 74(9), 1115-1119. https://doi.org/10.1007/s11746997-0033-0

Dia, V. P., Garcia, V. V., Mabesa, R. C., \& Tecson-Mendoza, E. M. (2005). Comparative physicochemical characteristics of virgin coconut oil produced by different methods. Philippine Agricultural Sciences, 88, 462-475.

Diaz, R., Sarmiento, J., Cormenzana, A., Cabo, P., \& Cabo, J. (1988). Phytochemical and antibacterial screening of some species of Spanish Lamiaceae. Fitoterapia, 59, 330-333. 
Friedrich, W. (1988). Vitamins. Walter de Gruyter.

Gharib, F. A. E.-L., \& da Silva, J. A. T. (2013). Composition, Total Phenolic Content and Antioxidant Activity of the Essential Oil of Four Lamiaceae Herbs. Medicinal and Aromatic Plant Science and Biotechnology, 7(1), 19-27.

Gupta, N., \& Saxena, G. (2010). Antimicrobial activity of contituents identified in essential oils from Mentha and Cinnamomum through GC-MS. International Journal of Pharma and Bio Science, 1(4), 23-31.

Hamilton, R. J., \& Allen, J. C. (1994). Rancidity in Foods. Blackie Academic and Professional.

Han, S. S., Lo, S. C., Choi, Y. W., Kim, J. H., \& Baek, S. H. (2004). Antioxidant activity of crude extract and pure compounds of Acer ginnala Max. Bulletin of the Korean Chemical Society, 25(3), 389-391.

Kamariah, L., Azmi, A., Rosmawati, A., Wai Ching, M., Azlina, M. D., Sivapragasam, A., Tan, C., \& Lai, O. (2008). Physico-chemical and quality characteristics of virgin coconut oil - A Malaysian survey (Ciri-ciri kimia fizikal dan kualiti minyak kelapa dara - Tinjauan di Malaysia). J. Trop. Agric. and Fd. Sc, 36(2), 1-10.

Kim, J. S. (2005). Radical scavenging capacity and antioxidant activity of the $E$ vitamer fraction in rice bran. Journal of Food Science, 70(3), 1-6. https://doi. org/10.1111/j.1365-2621.2005.tb07127.x

Laitupa, F., \& Susane, H. (2010). Pemanfaatan eugenol dari minyak cengkeh untuk Mangatasi Ranciditas Pada Minyak Kelapa. Jurusan Teknik Kimia, Fakultas Teknik. Universitas Diponegoro., 024, 1-10.

Loung, F. S., Silalahi, J., \& Suryanto, D. (2014). Antibacterial activity of enzymatic hydrolyzed of virgin coconut oil and palm kernel oil against staphylococcus aureus, Salmonella thypi and Escherichia coli. International Journal of PharmTech Research, 6(2), 628-633.

McKay, D. L., \& Blumberg, J. B. (2006). A review of the bioactivity and potential health benefits of peppermint tea (Mentha piperita L.). Phytotherapy Research, 20(8), 619-633. https://doi.org/10.1002/ptr.1936

Molyneux, P. (2004). The Use of the Stable Free Radical Diphenylpicryl-hydrazyl (DPPH) for Estimating Antioxidant Activity. Songklanakarin Journal of Science and Technology, 26(2), 211-219. https://doi. org/10.1287/isre.6.2.144

Muik, B., Lend, B., Molina-Diaz, A., \& Ayoea-Canada, M. J. (2005). Direct monitoring of lipid oxidation in edible oils by Fourier transform Raman spectroscopy. Chemistry Physics of Lipids, 134, 173-182.

National Standardization Agency. (2008). Virgin Coconut Oil (INS 7381:2008). In Indonesian National Standard (pp. 1-28).

Nurhasanah, D., Prasetyorini, \& Susilo, H. (2006). Uji efektivitas gel hand sanitizer minyak atsiri daun Mint (Mentha arvensis, L.).
Onyeike, E. N., \& Acheru, G. N. (2002). Chemical composition of selected Nigerian oil seeds and physicochemical properties of the oil extracts. Food Chemistry, 77(431437).

Pignitter, M., \& Somoza, V. (2012). Critical evaluation of methods for the measurement of oxidative rancidity in vegetable oils. Journal of Food and Drug Analysis, 20(4), 772-777. https://doi.org/10.6227/jfda.2012200305

Pokorny. (1971). Stabilization of Fat by Phenollic Antioxidants. Canadian Institute of Food Technology Journal, 18(2), 71-78.

Preedy, V. R., \& Watson, R. R. (2010). Olives and Olive Oil in Health and Disease Prevention. Elsevier Inc.

Rahmadi, A., Abdiah, I., Dewi, M., \& Purna, T. (2013). KARAKTERISTIK FISIKOKIMIA DAN ANTIBAKTERI VIRGIN COCONUT OIL HASIL FERMENTASI BAKTERI ASAM LAKTAT [ Physicochemical and Antibacterial Characteristics of Virgin Coconut Oil Fermented with Lactic Acid Bacteria ]. December 2013, 151-156. https:// doi.org/10.6066/jtip.2013.24.2.151

Richardsa, A., Wijesunderaa, C., \& Salisbury, P. (2005). Evaluation of oxidative stability of canola oils by headspace analysis. Journal of the American Oil CHemists Society, 82, 869-874.

Robinson, T. (1991). The Organic Constituens of Higher Plants. ITB Press.

Rohaman, M. M., Solechan, Trismansyah, D., \& Soeharto. (1998). Penggunaan Antioksidan Alami pada Minyak Kelapa. Journal of Agro-Based Industry, 15(1-2), 49-56.

Rohman, A., Che Man, Y. B., Ismail, A., \& Hashim, P. (2011). Monitoring the oxidative stability of virgin coconut oil during oven test using chemical indexes and FTIR spectroscopy. International Food Research Journal, 18(1), 303-310.

Satheesh, N., \& Prasad, N. B. L. (2014). Production of virgin coconut oil by induced fermentation with Lactobacillus plantarum NDRI strain 184. Croatian Journal of Food Technology, Biotechnology and Nutrition, 9(1-2), 3742. https://doi.org/10.1007/s00253-005-0297-y

Shrivastava, A. (2009). A review on peppermint oil. Asian Journal of Pharmaceutical and Clinical Research, 2(2), 27-33.

Silalahi, J., Yademe, T. P., \& Putra, E. D. (2014). Antibacterial activity of hydrolyzed virgin coconut oil. Asian Journal of Pharmaceutical and Clinical Research, 7(2), 90-94.

Singh, R., Shushni, M. A. M., \& Belkheir, A. (2015). Antibacterial and antioxidant activities of Mentha piperita L. Arabian Journal of Chemistry, 8(3), 322-328. https://doi. org/10.1016/j.arabjc.2011.01.019

Talapessy, S., Suryanto, E., \& Yudistira, A. (2013). Uji Aktivitas Antioksidan dari AMpas Hasil Pengolahan Sagu (Metroxylon sagu Rottb). Jurnal Ilmiah Farmasi, 2(03), 40-44. 
Tomagola, N., Muthiawati, N., Wiyani, L., \& Jaya, F. (2016). Aktivitas antioksidan ekstrak kayu manis (Cinnamomum burmanii) untuk mengatas ketengikan pada minyak goreng. Journal of Chemical Process Engineering, 01(02), 7-15.

Utami, O. Y. (2011). Komponen Minyak Atsiri Daun Sirih (Piper Betle L.) dan Potensinya dalam Mencegah Ketengikan Minyak Kelapa.
Wanasundara, U. N., \& Shahidi, F. (1994). Canola extract as an alternative natural antioxidant for canola oil. Journal of the American Oil Chemist Society, 71, 817-822.

Zuhra, C. F., Tarigan, J. B., \& Siihotang, H. (2008). Aktivitas antioksidan senyawa flavonoid dari daun katuk (Sauropus androgunus (L) Merr). Jurnal Biologi Sumatera, 3(1), 7-10. 